Session 3592

\title{
A Mentoring Guide for Female Faculty in Engineering
}

\author{
Susan L. Murray, Linda M. Manning, Catherine A. Riordan, \\ Elizabeth Cummins and Philip B. Thompson \\ University of Missouri-Rolla
}

\begin{abstract}
One widely accepted method for increasing the chances of success of female engineering and science students and faculty alike is to provide access to female role models and mentors. In this article we offer to new female faculty, and to those who would mentor them, an annotated list of text and electronic resources that address most of the most important challenges facing new female faculty in science and engineering.

\section{Introduction}

The process of mentoring in which a senior, more established scholar provides guidance regarding the career and intellectual needs of a junior colleague, is viewed by most to be vital to the success of scholars and young faculty members. Yet, many junior faculty, especially women and minorities in science and engineering fields, have no relationship with a senior faculty member who fulfills all aspects of the mentor role. While it is difficult to establish empirically why mentor relationships do not develop, some have argued that in the case of women, the close personal nature of the cross gender mentoring relationship presents unique problems or risks to potential mentors [3]. Additionally, reluctance stemming from assumed gender differences, habits, or less innocent assumptions about new female faculty members are cited as possible explanations [3]. Regardless of the reason, it seems to be widely believed that female faculty members in engineering and science are at a disadvantage in developing these very important mentoring relationships.
\end{abstract}

Female engineers may have even greater need for the types of support mentors can give because of the challenges they face in engineering. "While a man considers engineering to be a career, a woman--to be successful--must also consider it to be a crusade; and besides brains and ability, a woman needs mettle to make it in engineering" are two points made in a forum of leading female engineers sponsored by The Institute of Electrical and Electronics Engineers [1]. These national leaders agreed that mentoring has been an important support system for those women who have found the easiest paths to success. Overall, their discussion described significant interpersonal challenges that female engineers face--above and beyond the widely acknowledged academic challenges of the engineering curricula faced by all engineers.

This article includes a list of text and web resources we have found useful in our own careers. The list is by no means comprehensive, but it is nevertheless a very useful resource for new faculty members. Our own expertise with new faculty comes from a variety of sources. Some of us are new faculty members making the adjustments, while others are mentors for protégés so engaged. The resources we have selected and recommendations we make are flavored by that experience. We believe this guide will be of use to new engineering faculty by informing 
them, as a mentor would, of considerations most important to their success. We also hope others concerned about the success of new faculty will find information and encouragement they can bring to their efforts on behalf of new faculty.

\section{Annotated Resource List}

\section{Perspectives on Being a Female Faculty Member}

Lifting a Ton of Feathers: A Woman's Guide to Surviving in the Academic World (1993). Paula J. Caplan. Toronto: University of Toronto Press. ISBN: 0802074111. Intended as a handbook for female academics, from graduate students to faculty. The book serves several important functions. It validates the perceptions of those who experience a "chilly climate" on campus, while respecting those who do not. It provides excellent strategies for avoiding selfblame, understanding the academic environment, and meeting professional criteria.

Ms. Mentor's Impeccable Advice for Women in Academia (1997). Emily Toth. Philadelphia: University of Pennsylvania Press. ISBN: 0812215664. Witty, candid handbook on the tenure process. Toth gives excellent advice for navigating the scholarly and political waters.

Rhythms of Academic Life: Personal Accounts of Careers in Academia (1996). Peter J. Frost \& Susan M. Taylor. Thousand Oaks, CA: Sage Publications. ISBN: 0803972636. Volume in Sage's Foundations for Organizational Science series. Some titles of the 52 chapters give a flavor of the work: "Becoming a teacher at a research university"; "Using programmatic research to build a grounded theory"; "Getting tenure"; "Thoughts on integrating work and nonwork lives"; "Growing a personal, professional collaboration"; "Becoming a reviewer: Lessons somewhat painfully learned"; "Dealing with the overenriched work life"; and "working with policy makers."

Survival Skills for Scholars (1993-1997). Mitchell Allen (Mgr. Ed.). Newbury Park: Sage Publications. ISBN: 003952163. Series of small paperback books with advice for professors. As a series they give a comprehensive overview of the critical issues facing faculty members in their roles as teacher, researcher, service provider, consultant, media representative and writer, and in processes like tenure, ethical dilemmas, and coping with stress.

Useful Websites

http://www.cs.yale.edu/homes/tap/faculty.html. http://www.sau.edu/cwis/internet/wild/Faculty/Faculty/fayindex.htm.

\section{Teaching Improvement Resources}

The Chalk Dust Collection: Thoughts and Reflections on Teaching in Colleges and Universities (1996). Linc Fisch. Stillwater: New Forums Press. ISBN: 0913507695. Collection of 35 essays offering, in both serious and lighthearted ways, tips for professors. A few chapter titles reveal the approach, coverage, and relevance to new science and engineering professors: "Coaching mathematics and other academic sports," "Seven principles of teaching seldom taught in graduate 
school," and "The case for leaving things out." This is a delightful read and a stimulus for rethinking classroom techniques.

Science Teaching Reconsidered: A Handbook (1997). Committee on Undergraduate Science Education. Washington, D.C.: National Academy Press. ISBN: 0309054982. Also available on the web at http://www.nap.edu/readingroom/books/str/contents.html. Succinct and direct, it covers the most recent knowledge and issues in the basics of teaching. The chapters include discussions of teaching styles, course syllabi, large lecture classes, effective lecturing and laboratories, teaching assistants, textbook selection, information technologies, math anxiety, humanizing science. The appendices include addresses to relevant organizations, to periodicals in undergraduate science education, and laboratory issues. Everyone we've sent to the reference has been delighted - and not just because it's free.

Teaching Websites for Engineering Instructors http://www.engr.uiuc.edu/TEIS/bibliography.html. http://www.academic.com.

http://www.aln.org.

http://www.educom.edu.

\section{$\underline{\text { Research }}$}

The Craft of Research (1995). Wayne C. Booth, Gregory G. Colomb, \& Joseph M. Williams. Chicago: Univ. of Chicago Press. ISBN: 0226065847. Covers many aspects of research, beginning with a general overview of the purposes and uses of research, then moving to a discussion of topic selection and how to discover and use sources of information. The remainder concerns structuring the argument, writing and revising drafts, and the mechanics of clear exposition.

Get Funded! A Practical Guide for Scholars Seeking Research Support from Business (1992). Dorin Schumacher. Newbury Park: Sage Publications. ISBN: 0803944411. One of the few resources dealing specifically with seeking corporate support for research. Included are company pet peeves when working with academics, corporate terminology, political and financial issues facing R\&D staff, etiquette of company contacts, and even an outline for an introductory presentation to the company. This is an excellent book for new faculty who have never worked in a corporate environment or had little exposure to successful corporate-university collaborations.

Research Funding Opportunities Website http://www.crpc.rice.edu/TRAM.

\section{Gender Focused Issues}

Academic Mentoring for Women Students and Faculty: A New Look at an Old Way to Get Ahead (1983). Roberta M. Hall \& Bernice R. Sandler, Project on the Status and Education of Women. Available from the Association of American Colleges, 1818 R Street, NW, 
Washington, D.C. 20009; (202) 387-3760. Asserts that women who are often on the margin of academia's colleague systems may not learn the standards of professional behavior which are informally determined and distributed. Contains an insightful list of mentoring benefits for the mentor, the protégé, and the institution. Addresses several barriers to good mentoring relationships, along with types of mentoring available, and how to establish mentoring relationships. There are also tips on how to be a mentor and what institutions can do to promote mentoring. This report addresses both traditional and non-traditional mentoring strategies, and a variety of resources, including programs and organizations, many of which are listed in the bibliography.

Nobel Prize Women in Science: Their Lives, Struggles, and Momentous Discoveries (1993). Sharon Bertsch McGrayne. New York: Birch Lane. ISBN: 1559721464. An entertaining and candid collection of biographies profiling fourteen women who won the Nobel Prize or contributed to a project that won the Nobel. McGrayne pursues an answer to the question, why have so few (under 3\%) of Nobel Prize winners have been women? These informal narratives, accompanied by photographs, reveal not only the obstacles these women faced but also the conditions that made the women successful: love of science, supportive family members, emphasis on education in their religious background, male mentors, and the first women's movement.

Subtle Sexism: Current Practices and Prospects for Change (1997). Nijole V. Benokraitis. Thousand Oaks: Sage Publications. ISBN: 0761903860. According to the authors, the purpose of this book is to "sensitize" readers to the widespread prevalence of subtle sexism and to suggest how such practices can be changed (p. xii). Subtle sexism includes "condescending chivalry, supportive discouragement, friendly harassment, radiant devaluation, liberated sexism and benevolent exploitation." An excellent source book for those concerned about the climate for women or subtle forms of discrimination. See also Antifeminism in the Academy (1996). $\mathrm{Ve}^{\prime} \mathrm{Ve}^{\prime} \mathrm{Clark}$, Shirley Nelson Garner, Margaret Higonnnet, \& Ketu H. Katrak (Eds.). New York: Routledge. ISBN: 0415910714.

Women Faculty at Work in the Classroom: or Why it Still Hurts to be a Woman in Labor (1993). Bernice R. Sandler. Washington, D.C.: Center for Women Policy Studies. ISBN: 1877966150. Describes the differences in the ways that male and female students treat female and male faculty. Different expectations for men and women exist, and female instructors tend to be devalued, in part because of the way they communicate. For administrators, there are strategies designed to make classroom behavior a topic for campus-wide discussion, develop appropriate policies, and provide training for faculty and administrators. The paper also provides a good bibliography on the chilly climate.

\section{Humorous Perspectives}

Moo (1995). Jane Smiley. New York: Ivy Books. ISBN: 0804117683. This novel is set at a fictitious Midwest land grant institution, Moo University, and filled with outlandish characters, familiar to those in academia. There is the department chair engaged in a bloody feud via memorandums, the overly ambitious development officer, the domineering administrative 
assistant controlling the university, and a struggling new assistant professor. Moo is a nice escape.

$\underline{\text { The Dilbert Zone }}$

http://www.unitedmedia.com/comics/dilbert. Dilbert's webpage with archive of recent comic strips. A must for engineers!

\section{Organizations}

\section{AAUW Hotlist}

http://www.ianet.com/aauw/hotlist.html. Offers links to sites for women in science and engineering. Our two favorite site links include Educational Issues for Women in Science and Engineering, and Women's Issues and Gender Differences in Science and Engineering.

American Society of Engineering Education (ASEE)

http://www.asee.org. This organization seeks to improve all aspects of engineering education through activities ranging from its publications, building a data base about engineering education practices and professionals, national and regional conferences, and awards.

Society of Women Engineers (SWE)

http://www.swe.org. This organization's purpose is to "stimulate women to their full potential in careers as engineers and leaders, expand the image of the engineering profession as a positive force in improving the quality of life, and demonstrate the value of diversity." SWE Headquarters is at 120 Wall Street, $11^{\text {th }}$ Floor, New York, New York 10005-3902. The phone number is $212 / 509-9577$. Email is hq@swe.org. The Web site includes the SWE Magazine and references to other sites.

Women in Engineering Program Advocates Network (WEPAN)

http://www.engr.washington.edu/ wepan/index.html. This organization's mission is to increase the number of women pursuing careers in engineering with activities ranging from pre-college to industry professionals. Includes links of particular interest to computer scientists, marine biologists, geoscientists, mathematicians, engineers, and information technology professional generally.

\section{Listservs and Electronic Journals}

ASEE Women in Engineering Division. To subscribe to this listserv send a message with the subject area left blank to Wied-L@ vm.cc.purdue.edu. In the message portion type: SUBSCRIBE WIED-L.

Women in Higher Education

http://www.itis.com/wihe. A national monthly electronic journal for women faculty members to "enlighten, encourage, empower, and enrage." The site has links to current and back issues of Women in Higher Education, career connections, and miscellaneous information of interest to women on campus.

Women in Science and Engineering NETwork WISENET@listserv.uic.edu 
Links to resources, societies, associations, projects, centers, and references for women in science and engineering.

\section{Collection of online writings and resources by/about/for women}

http://www.mit.edu:8001/people/sorokin/women

http://www.math.purdue.edu/ jer/women.html.

http://www.ai.mit.edu/people/ellens/Gender/wom_and_min.html

http://ee.utah.edu/ bcox/conference/women.html

\section{References}

[1] Geppert, L. (1995, May). The uphill struggle: No rose garden for women in engineering. IEEE Spectrum, 4050.

[2] Riordan, C., Manning, L., Daniel, A., Murray, S., Thompson, P., and Cummins, E. (Accepted). If I Knew Then What I Know Now: A Portable Mentor for Women Beginning Professional Careers in Science and Engineering. Journal of Women and Minorities in Science and Engineering.

[3] Sandler, B.R. (1986). The campus climate revisited: Chilly climate for women faculty, administrators, and graduate students. Project on the Status and Education of Women, Association of American Colleges.

\section{Biographical Information}

SUSAN L. MURRAY is an assistant professor of engineering management at the University of Missouri-Rolla. She received her Ph.D. in industrial engineering from Texas A\&M University. Dr. Murray is currently serving as the secretary of the engineering management division of ASEE.

LINDA M. MANNING is an associate professor of economics at the University of Missouri-Rolla. She received her Ph.D. in economics from the University of Illinois.

CATHERINE A. RIORDAN is director of management systems and professor of psychology at the University of Missouri-Rolla. She received her Ph.D. in psychology from the State University of New York at Albany.

ELIZABETH CUMMINS is chair and professor of English at the University of Missouri-Rolla. She received her Ph.D. in English from the University of Illinois-Urbana.

PHILIP B. THOMPSON is a visiting assistant professor of economics at the University of Missouri-Rolla. He received his Ph.D. in Economics from the University of Arizona. 